\title{
The First Witnesses. Martha, Longinus and Veronica in the Slavic Manuscript Tradition (Initial Observations)
}

The objective of the following study is to trace the fate - as it is related in the literature of the Orthodox Slavs - of three characters known to us from Early Christian sources. The first of them appears under her own name in the canonical Gospels, where the second is also referred to (albeit rather imprecisely, and anonymously), while the third - originally a legendary figure - became 'canonical' though identification with another anonymous character from the New Testament.

The material which we shall utilize to portray those three characters comprises literary texts written hundreds of years apart, from the Ancient Christian times $\left(2^{\text {nd }}-3^{\text {rd }}\right.$ centuries) until the close of the Middle Ages (the Tale of Martha $-15^{\text {th }}$ century) and originating from diverse cultural milieus. From among those that are employed in liturgy, we may mention the 'microgenre' of the sticheron (a verse sung during service conveying the fundamental significance of the liturgical holiday), the so-called 'short' or 'prologue' lives of saints (found in the menologia in chronological order), the 'extended' lives (vita, gesta, enriching the factual material with rhetorical elements) and the passions (passio). Another, lower register of the medieval system of genres is comprised by the customarily more popular texts such as the 'tales' (known as slovo, literally 'word', in the Slavic literary tradition and occasionally approximating the gesta: 'story' or narratio) and the legends, both genres incorporated and adapted into official texts. Texts belonging to the latter register - tales and legends - are not infrequently labelled as pseudo-canonical or apocryphal, although it should be noted that the term as employed here is, in a way, conventional.

The material under discussion largely includes texts that form a part of the Slavic Orthodox tradition, depicting them on the one hand against the background of fairly well-known works belonging to the Western Christian tradition; on the other hand, it should be highlighted that not all of them are original and unknown in the other linguistic traditions of Eastern Christianity. Quite the reverse, most of them are in fact translations or adaptations of texts originally stemming from the Byzantine heritage and have closely related counterparts in Latin, Syriac, Armenian, etc. It is 
often the case that the original Slavic compositional element may be identified by comparing the text with its sources in different languages.

The epithet 'first witnesses', conferred on the three saints in the title, is but a conventional designation; it seems fitting as common for the figures of Martha, Veronica and Longinus, all three of whom gave strong proof of their devotion to Christ. Otherwise, although they make no simultaneous appearance in any of the canonical texts, there are - interestingly - far more interconnections between the three characters in pseudo-canonical and legendary literature than could be surmised from the lack thereof in the Bible. Finally, it is my intention to point out how the Christian tradition exemplifies various manifestations of holiness, what means it has for annotating, elucidating and embellishing the Biblical hypertext, and how it adapts pseudo-canonical legends for the purposes of liturgical use.

\section{Martha ${ }^{1}$}

From among the three characters under discussion, Martha, the sister of Mary and Lazarus, is the best 'documented'. The siblings from Bethany have been attributed noble birth; in the pseudo-canonical Armenian Gospel of the Infancy, it is maintained that they were the offspring of a certain Eleazar, a prince of Hebrew descent ${ }^{2}$. Martha comes to light in the canonical Gospels, where she witnesses the great miracle of her brother being brought back to life in the scene known as the resurrection of Lazarus ${ }^{3}$ :

John 11, 1-5; 11, 17-27; 11, 38-44: Now a man named Lazarus was sick. He was from Bethany, the village of Mary and her sister Martha. (This Mary, whose brother Lazarus now lay sick, was the same one who poured perfume on the Lord and wiped his feet with her hair.) So the sisters sent word to Jesus, "Lord, the one you love is sick." When he heard this, Jesus said, "This sickness will not end in death. No, it is for God's glory so that God's Son may be glori-

1 Recently, numerous studies devoted to the figure of Martha have been published, cf. e.g. N. Corson Carter, Martha, Mary and Jesus: Weaving Action and Contemplation in Daily Life, Collegeville 1992; P.F. EsLer, R. PIPER, Lazarus, Mary and Martha: Social-Scientific Approaches to the Gospel of John, Minneapolis 2006, and especially: M.M. DAas, From Holy Hostess to Dragon Tamer: the Anomaly of Saint Martha, LT 22.1, 2008, p. 1-15; furthermore: A.M. ERNsT, Martha from the Margins: The Authority of Martha in Early Christian Tradition, Leiden-Boston 2009.

2 The Apocryphal New Testament: Being the Apocryphal Gospels, Acts, Epistles, and Apocalypses, with Other Narratives and Fragments, ed. M.R. James, Oxford 1924, p. 83. Cf. also the entire text in: The Armenian Gospel of the Infancy, with Three Early Versions of the Protevangelium of James, ed. A. Terian, Oxford 2008. Furthermore, cf. the remarks on the background of Mary Magdalene (as presented in the sermons of Catholic priests in Poland) in: M. Kuran, Postać św. Marii Magdaleny w staropolskim kaznodziejstwie wobec tradycji apokryficznych, [in:] Biblia Slavorum Apocryphorum. Novum Testamentum. Materiały z Międzynarodowej Konferencji Naukowej, Łódź, 15-17 maja 2009, ed. G. Minczew, M. Skowronek, I. Petrov, Łódź 2009, p. 77-91.

3 The same episode is also related in further pseudo-canonical works, e.g. the Georgian Gospel (Evangelium Ibericum), cf. the Polish translation by G. Peradze: Apokryfy Nowego Testamentu, vol. I, Ewangelie apokryficzne, pars 1, ed. M. STAROWIEYSKI, Kraków 2003, p. 204-229. 
fied through it." Now Jesus loved Martha and her sister and Lazarus. [...] On his arrival, Jesus found that Lazarus had already been in the tomb for four days. Now Bethany was less than two miles from Jerusalem, and many Jews had come to Martha and Mary to comfort them in the loss of their brother. When Martha heard that Jesus was coming, she went out to meet him, but Mary stayed at home. "Lord," Martha said to Jesus, "if you had been here, my brother would not have died. But I know that even now God will give you whatever you ask." Jesus said to her, "Your brother will rise again." Martha answered, "I know he will rise again in the resurrection at the last day." Jesus said to her, "I am the resurrection and the life. The one who believes in me will live, even though they die; and whoever lives by believing in me will never die. Do you believe this?" "Yes, Lord," she replied, "I believe that you are the Messiah, the Son of God, who is to come into the world." [...] Jesus, once more deeply moved, came to the tomb. It was a cave with a stone laid across the entrance. "Take away the stone," he said. "But, Lord," said Martha, the sister of the dead man, "by this time there is a bad odour, for he has been there four days." Then Jesus said, "Did I not tell you that if you believe, you will see the glory of God?" So they took away the stone. Then Jesus looked up and said, "Father, I thank you that you have heard me. I knew that you always hear me, but I said this for the benefit of the people standing here, that they may believe that you sent me." When he had said this, Jesus called in a loud voice, "Lazarus, come out!" The dead man came out, his hands and feet wrapped with strips of linen, and a cloth around his face. Jesus said to them, "Take off the grave clothes and let him go."

There is no mention of the miracle of the resurrection of Lazarus in the synoptic Gospels; an account is only provided by John.

Martha, whose name (of Aramaic origin) means 'lady', is furthermore referred to in two other passages: in the context of her family ties, as well as with emphasis on her diligence and care for the household, which latter characteristic has become the Saint's distinctive feature and given the basis for the worship of Martha as the patron saint of cooks and household wives (at least in the Western tradition):

Luke 10, 38-42: As Jesus and his disciples were on their way, he came to a village where a woman named Martha opened her home to him. She had a sister called Mary, who sat at the Lord's feet listening to what he said. But Martha was distracted by all the preparations that had to be made. She came to him and asked, "Lord, don't you care that my sister has left me to do the work by myself? Tell her to help me!" "Martha, Martha," the Lord answered, "you are worried and upset about many things, but few things are needed - or indeed only one. Mary has chosen what is better, and it will not be taken away from her."

John 12, 1-2: Six days before the Passover, Jesus came to Bethany, where Lazarus lived, whom Jesus had raised from the dead. Here a dinner was given in Jesus' honour. Martha served, while Lazarus was among those reclining at the table with him.

4 This and all the following quotations from the Bible follow the New International Version, quoted after http://www.biblica.com/bible/browse-books/ [20 X 2011]. 
These passages from the Scripture have earned Martha the honourable title of Hospita Christi - 'the hostess of Christ', attested e.g. in the Martyrologium Romanum ${ }^{5}$. On the basis of those excerpts from the Gospels, Biblical scholars and exegetes interpret the figure of Martha as supplementary for the contemplative attitude of her sister ${ }^{6}$, although the first of the quotations provided above brilliantly illustrates the former's ardent faith.

The liturgical commemoration of Saint Martha of Bethany takes place on 29 July in the calendar of the Western Church, and on 4(17) June in the East (where she is worshipped alongside Mary). The sticheron dedicated to the sisters reads: $\bar{w}$

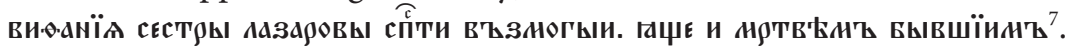

Nevertheless, Martha is commemorated twice more in the East: in the liturgy of Lazarus Saturday (before Palm Sunday) ${ }^{8}$ as well as on the so-called Sunday of the Myrrhbearers (the second Sunday after Easter). The latter commemoration has its roots in the traditional conviction - not expressed in the canonical Gospels, however - that Martha is one of the women carrying the ointments for Christ, the latter already taken down from the Cross and buried. John speaks of Mary Magdalene solely in this context (John 19, 25); Matthew mentions Mary Magdalene and another Mary (Matthew 28, 1), while Luke enumerates Mary Magdalene, Joanna and Mary the mother of James (Luke 24, 10). Finally, Mark writes that „some women were watching [Christ's death] from a distance. Among them were Mary Magdalene, Mary the mother of James the younger and of Joses, and Salome" (Mark 15, 40). It is in all likelihood this reference to 'them' that has elicited the speculations about there being further women among those accompanying and serving Jesus in Galilee, including Martha. In the pseudo-canonical Epistula Apostolorum (Epistle of the Apostles, dated to the $2^{\text {nd }}$ century and known in four versions: Greek, Latin, Ethiopic and Coptic), containing an outstandingly high number of quotations from the canonical Gospels, we read: [Jesus] was buried in a place which is called the place of the skull, to which three women came, Sarah, Martha and Mary Magdalene. They carried ointment to pour out upon his body, weeping and mourning over what had happened... ${ }^{9}$ As can be

5 Martyrologium romanum: Tarasci, in Gallia Narbonensi, sanctae Marthae Virginis, hospitae Salvatoris nostri ac sororis beatorum Mariae Magdalenae et Lazari, http://divinumofficium.com/www/ horas/Latin/Martyrologium/07-29.txt [20 X 2011].

6 Religia. Encyklopedia PWN, vol. VI, ed. T. GadAcz, B. Milerski, Warszawa 2006.

7 You deigned to save the sisters of Lazarus of Bethany, though after his death, quoted after: Г. ПЕтков, Стишният пролог в старата българска, сръбска и руска литература. Археограбия, текстология и издание на проложни стихове, Пловдив 2000, p. 413.

8 The BHG catalogue (ed. F. Halkin, Bruxelles 1953) only mentions one sermon (among over thirty for that day) in which Lazarus is commemorated together with his sisters in the title (cf. vol. III, Lazarus a Betania, Amicus Christi, quatriduanus, p. 39-43). The Bibliotheca Hagiografica Balcano-Slavica catalogue (К. ИвАновА, София 2008) does not list 4 June as a day of commemorating Saint Martha at all.

9 Epistula Apostolorum ('Epistle of the Apostles'), [in:] The Apocryphal New Testament: A Collection 
seen, the account of this event as preserved in the Epistula Apostolorum diverges from the canonical variants: the Four Gospels mention neither the presence of Martha nor the woman named Sarah. Although certain (Western) versions of the life of Martha claim that she watched [...] the death of Jesus, her God, and saw His resurrection alongside the other disciples ${ }^{10}$, she is not usually included among the women lamenting the Passion of Christ on Mount Golgotha.

Martha is also depicted as a person of profound piety and zealousness in the work known as Pistis Sophia ('Faith-Wisdom'). It is a gnostic text composed around the $2^{\text {nd }}-3^{\text {rd }}$ centuries in the Greek language and preserved in its entirety in one of the Coptic dialects; its title refers to one of the highest female Aeons. The work has the form of a collection of dialogues between Jesus and the disciples (predominantly John and Mary Magdalene) twelve years after the Resurrection, organized into 113 chapters $^{11}$. Chapter 38 mentions the presence of Martha among the disciples and relates how she, blessed by the Lord, inspired by the Spirit, describes the grace of penance received from Pistis Sophia and praises Christ by singing a psalm ${ }^{12}$. It would be difficult to establish any direct link with text of the canonical Gospels; only in the gnostic Gospel of the Egyptians and in the Gospel According to Mary Magdalene does Christ speak to his female disciples, singling them out from among the Apostles.

of Apocryphal Christian Literature in an English Translation Based on M.R. James, ed. J.K. ELLIotT, Oxford 1993, p. 561 (entire text on p. 555-590).

${ }^{10}$ Żywot Świętej Marty, dziewicy, [in:] P. SKarGa, Żywoty Świętych Pańskich na wszystkie dni roku, Katowice-Mikołów 1937, http://ruda_parafianin.republika.pl/swi/m/marta.htm [20 X 2011].

${ }^{11}$ Translations of the entire work are available online: http://gnosis.org/library/pistis-sophia/ps042. htm [20 X 2011] (English) and http://www.krotov.info/acts/03/3/pistis.htm [20 X 2011] (Russian). Excerpts in Polish (trans. R. Szmur£A) are to be found in Apokryfy Nowego Testamentu..., vol. I, p. $159-162$.

${ }_{12}$ And it came to pass, when Jesus had finished speaking these words unto his disciples, saying: "This is the third repentance of Pistis Sophia", that he said unto them: "Let him in whom a sensitive spirit hath arisen, come forward and speak the thought of the repentance which Pistis Sophia hath uttered". It came to pass then, before Jesus had finished speaking, that Martha came forward, fell down at his feet, kissed them, cried aloud and wept with lamentation and in humbleness, saying: "My Lord, have mercy upon me and have compassion with me, and let me speak the solution of the repentance which Pistis Sophia hath uttered". And Jesus gave his hand unto Martha and said unto her: "Blessed is every one who humbleth himself, for on him they shall have mercy. Now, therefore, Martha, art thou blessed. But proclaim then the solution of the thought of the repentance of Pistis Sophia". And Martha answered and said unto Jesus in the midst of the disciples: "Concerning the repentance which Pistis Sophia hath uttered, O my Lord Jesus, of it thy light-power in David prophesied aforetime in the sixty-ninth Psalm, saying: 1. O Lord God, give heed to my help. 2. Let them be put to shame and con-founded who seek after my soul. 3. May they turn straightway and be put to shame, who say unto me: Ha, ha. 4. May all who seek thee, be joyful and exult because of thee, and they who love thy salvation, say ever: May God be exalted. 5. But I am wretched, I am poor; O Lord, help me. Thou art my helper and defence; O Lord, delay not". "This then is the solution of the third repentance which Pistis Sophia hath uttered, singing praises to the height" - Pistis Sophia, trans. G.S.R. MEAD, http:/gnosis. org/library/pistis-sophia/ps042.htm [20 X 2011]. 
The Orthodox Church worships the Sisters from Bethany as martyrs, a fact probably connected with the account according to which - after the death of the Stephen, the First Martyr - Mary and Martha left Jerusalem accompanying Lazarus, whom they supported in preaching the word of Christ. All three are related to have perished on Cyprus, where Lazarus had become the first bishop ${ }^{13}$. An alternative explanation assumes a transfer (contamination?) of the type of holiness from two other female martyrs by the same names, stemming from Caesarea ${ }^{14}$. Nevertheless, no sources that would enable us to solve this question beyond all doubt have survived.

Conversely, no such doubts are faced by the Western Christian tradition, whose main vehicle comprises two texts: The Life of St. Mary Magdalene and of Her Sister St. Martha by Rabanus Maurus (788-856) ${ }^{15}$ as well as its considerably simplified adaptation (making use of some of the information found in the original) of the story of Saint Martha included in Jacobus de Voragine's Legenda Aurea (Golden Legend, $13^{\text {th }}$ century) $)^{16}$.

The vita compiled by Rabanus Maurus enjoyed indubitable prestige. This extensive work, divided into 50 chapters and markedly rhetorical in character, comments with unparalleled meticulousness on those passages of the New Testament where Martha appears. The Saint is portrayed in the context of her family background (she is said to be the daughter of the Syrian Theophilus and Eucharia) and delineated as an exceptionally strong personality. After the Ascension and the banishment by pagans (or Jews), Martha is claimed to have reached the southern shores of France (the place called Saintes Maries-sur-la-Mer, in the vicinity of Marseilles) in a ship without sails, oars or rudder, together with her siblings and Saint Maximilian, who had baptized them. Martha as described by the abbot of Fulda is not merely an inspired missionary (from Marseilles to the north, up to the Rhone), endowed with an outstanding gift of elocution, and a visionary (she sees Christ and the already deceased Mary Magdalene, and also predicts the moment of her own death), but also the founder of the church of the Blessed Virgin Mary, where she is said to have spent the rest of her life. Apart from that, she achieves an exceptional deed: she slays a dragon. In what is probably the most widely known legend associated with the name of Saint Martha, she is said to have subdued a ferocious dragon (called Tarasconus) that had harassed the local population. With the help of the cross and holy water, Martha is said to have

\footnotetext{
${ }_{13}$ Жития святых в изложении святителя Димитрия, митрополита Ростовского. Книга первая, 1689, http://www.ispovednik.ru/zhitij/oct/okt_17_Lazar.htm [20 X 2011].

${ }_{14}$ Девицы Марфа и Мария и Ликарион, [in:] Архиепископ Сергий (СпАсский), Полный месяцесвов Востока, vol. III, Святой Восток, Москва 1997, p. 60 [6 February].

${ }^{15}$ Rabanus Maurus, De Vita Beatae Mariae Magdalenae et Sororis Ejus Sanctae Marthae, [in:] PL, vol. CXII, col. 1441-1507; commented English translation: Rabanus MaUrus, The Life of St. Mary Magdalene and of Her Sister St. Martha, trans. D. Mycoff, Kalamazoo 1989.

${ }^{16}$ Saint Martha, [in:] Jacobus de Voragine, The Golden Legend: Readings on the Saints, trans. W. Granger Ryan, vol. II, Princeton 1993, p. 23-26.
} 
captured it and rendered it harmless, tying it up with her own belt (a topos recurring in stories related to other saints, e.g. Margaret of Antioch) ${ }^{17}$. Until today, the inhabitants of the commune of Tarascone (between Arles and Avignon) commemorate this accomplishment by organizing celebrations in the last weekend of June. The Life... also describes Martha's miraculous healings (performed both during her life and after death) as well as the resurrection of a drowned man.

Jacobus de Voragine ${ }^{18}$ makes use of the part of The Life... that deals with Martha; although he preserves the general form, he simplifies and sometimes distorts is. He extols Martha as the most "prudent" of the three siblings, one who kept close watch over her brother's and sister's estates and took care of the needs of her armed men, her servants, and the poor ${ }^{19}$.

The main idea of those tales or legends about the Saint which we shall here conventionally call 'Western' is, as it appears, the attempt to substantiate the notion of a remarkably early Christianization of Western Europe - already in the half of the $1^{\text {st }}$ century (further analogous stories about the Christianization of particular European lands at the hands of Christ's disciples exist; we may mention the one about Saint James the Greater in Spain). The anecdotal or even fantastical status of these accounts is utterly unquestionable, especially in view of the lack of any testimony whatsoever to the later life of Martha.

Considering the far-reaching discrepancies, it could seem that the stories about Saint Martha stemming from Eastern and Western Christianity actually describe two different characters. This is, however, not the case; at least two 'intersections' of the fates of the 'Eastern' and the 'Western' Martha can be identified on the legendary/ literary plane.

The first one is Eusebius of Caesarea's account (mentioned but abridged and simplified by de Voragine), according to which Martha is to be identified with the woman healed by Jesus from the issue of blood (Luke 8, 42-48). In gratitude, she decides to erect a monument for the Teacher:

But since I have come to mention this city ${ }^{20}$, I do not think it right to omit a story that is worthy to be recorded also for those that come after us. For they say that she who had an issue of blood, and who, as we learn from the sacred Gospels ${ }^{21}$, found at the hands of our Saviour relief from her affliction, came from this place, and that her house was pointed out in the city, and that marvellous memorials of the good deed, which the Saviour wrought upon her, still

${ }^{17}$ Others connect the story about Martha slaying the dragon with Celtic beliefs about monsters whose subjugation is to be an element of the canicular myth, cf. P. Walter, Christianity: The Origins of a Pagan Religion, trans. J.E. Graham, Rochester Vt. 2006.

${ }_{18}$ Saint Martha..., p. 24.

${ }^{19}$ Saint Mary Magdalene, [in:] Jacobus de Voragine, op. cit., vol. I, p. 375.

${ }^{20}$ Caesarea Philippi, also called Paneas.

${ }^{21}$ Matthew 9, Mark 5, Luke 5. 
remained. For [they said] that there stood on a lofty stone at the gates of her house a brazen figure in relief of a woman, bending on her knee and stretching forth her hands like a suppliant, while opposite to this there was another of the same material, an upright figure of a man, clothed in comely fashion in a double cloak and stretching out his hand to the woman. ${ }^{22}$

The above account constitutes an ancient and more complete version of a legend according to which there were - unlike in the Legenda Aurea - as many as two statues, of the healed and of the Healer ${ }^{23}$. The identification of the woman who reared the statue of Christ with Martha, as in the relation of Jacobus de Voragine, starts to appear beginning in the $12^{\text {th }}$ century in the writings of Western writers and theologians (Petrus Comestor, Gervase of Tilbury) ${ }^{24}$. Already earlier (in the $5^{\text {th }}-6^{\text {th }}$ century: Macarius Magnes, John Malalas), however, legends are recorded in the East according to which the woman was a princess named Berenice, a native of Edessa. This theme - both the city of Edessa and the name Berenice (Veronica), the latter associated with a number of originally anonymous female characters known from literary texts (such as the New Testament) and legends - is worth remembering, not without reason. Berenice/Veronica will appear in the context of other stories about the deeds and death of Christ. This can be seen the most clearly in the sixth Station of the Cross in the Western tradition, but is also noticeable in liturgical texts of the Eastern Church.

Another such point where the Eastern and Western variants of the story about Saint Martha overlap has its roots in the work called On How Martha Judged Pilate, also known as the Tale ('Slovo') of Martha ${ }^{25}$. In spite of having been published twice ${ }^{26}$, the text remains relatively unknown. It is an original Slavic compilation of motifs known from a number of pseudo-canonical works belonging to the so-called Pilate Cycle - a collection of texts narrating the circumstances and consequences of the Passion, developed in the course of a few centuries (from the $2^{\text {nd }} / 3^{\text {rd }}$ until the $11^{\text {th }} / 12^{\text {th }}$ century) in various languages (Greek, Latin, Italian). Students of the Slavic manuscript

\footnotetext{
${ }^{22}$ Eusebius, The Ecclesiastical History, VII, 18, 1-2, trans. K. LAKe, vol. II, London-New York 1926 (cetera: Eusebius), p. 175-177.

${ }^{23}$ J. Naumowicz, Posag Jezusa $z$ Paneas $w$ źródłach patrystycznych i bizantyńskich, [in:] Słowo i ikona. Źródła literackie w badaniach sztuki bizantyńskiej i postbizantyńskiej, ed. W. DelugA, Warszawa 2004 [SByz, 2], p. 43-54.

${ }^{24}$ J. PolívKa, Drobne príspěvky literárnĕ-historickĕ, Praha 1891, p. 9.

${ }^{25}$ In the scholarly literature the text is known under its Latin title Narratio de Martha, cf.: F.J. Thomson, Apocrypha Slavica: II, SEER 63, 1985, p. 81; The Medieval Gospel of Nicodemus. Texts, Intertexts, and Contexts in Western Europe, ed. Z. IzydorCZyK, Tempe 1997, p. 9 (= Medieval and Renaissance Texts and Studies, 158).

${ }^{26}$ The editions of The Tale of Martha: St. Novaković, Bugarski zbornik, pisan prošloga vieka narodnim jezikom, Star 6, 1874, p. 45-47 (a 17th century manuscript from the National Library of Serbia, cat. no. 106, destroyed during the bombings of World War II); Gj. PolívkA, Opisi i izvodi iz nekoliko jugoslavenskih rukopisa u Pragu, Star 24, 1891, p. 115-118 (text); Апокрифи і легенди з українських рукописів, sel. I. ФРАнко, vol. II, Апокрифи новозавітні, А, Апокрифічні євангелія, Львів 1889 [repr. 2006], p. 418-420; cf. F.J. Тномson, op. cit., p. 81-82.
} 
tradition (F.J. Thomson) distinguish two versions of the Tale of Martha, of which the older, more extensive one - probably written in the $15^{\text {th }}$ century in Bulgaria - is attributed to John Chrysostom ${ }^{27}$. The variants of the Tale of Martha that survive until today (at least 16 in number ${ }^{28}$ ) were composed between the $15^{\text {th }}$ and the $18^{\text {th }}$ century and represent both the Serbian and Bulgarian as well as the Russian recension of the Church Slavic language, which provides proof for the presence of the text in both the South and the East Slavic domain.

The plot of the Tale of Martha is the following: after the Ascension, Martha makes her way to Rome, to emperor Augustus, to whom she intends to confess the "truth" about Christ. To this end, she expounds the role of Pilate, the prefect, as well as of a Roman centurion named Longinus, in Christ's being sentenced do death. She also gives an account of the miracles done by Jesus, including the resurrection of Lazarus $^{29}$. Demanding a "confirmation", Augustus sends one of his servants (in the implied company of Martha) to Jerusalem. Afterwards, Martha returns to Rome together with her brother Lazarus and the centurion Longinus, who had "believed by himself". Christ's robe that Longinus has with himself causes "tremor" in the palace: when Longinus enters without the precious keepsake/relic, the "tremor" fades. Another trial of the emperor's faith is the healing of the ulcer in his nose; after he has made the sign of the cross and called the name of God, the ulcer disappears. Consequently, he confesses faith in Christ and is baptized (!). Next, accompanied by his army, he goes to Jerusalem, where he brings about the capture of Pilate. The latter, having himself asked for being condemned to torture, is decapitated, his head taken to heaven by angels. Caiaphas escapes "into the wilderness", only to be accidentally shot in the heart during a hunt ${ }^{30}$. Augustus makes yet another confession of his faith. The short version of the Tale of Martha diverges from its longer counterpart by omitting certain details, insignificant for the plot (moreover, the account of the tragic fate of Pilate and Caiaphas is left out; there are also no remarks on Longinus' possessing the robe of Christ ${ }^{31}$. Besides disparities in plot details, the various versions also diverge

\footnotetext{
${ }^{27}$ F.J. Thomson, op. cit., p. 81-82.

${ }^{28}$ Most of them are enumerated and classified in ibidem, p. 81-82.

${ }^{29}$ There are texts (also Slavic) in which the woman pleading for Christ in Rome is Mary Magdalene, whom he had cleansed from seven demons (The Reply of Emperor Tiberius Given to Pontius Pilate as Well as Governor Rahab and His Two Thousand Soldiers, quoted after: Ответ Тиверия кесаря Пилату Понтийскому и в ответ воеводе Рахааву и с ним воинам числом две тыссячи, [in:] Апокрифы Древней Руси, еd. М.В. Рождественская, Санкт-Петербург 2006, р. 136-137).

${ }^{30}$ The Letter of Tiberius to Pilate ends in a parallel episode, the difference lying in the fact that it relates the death of Pilate, cf. The Letter of Tiberius to Pilate, [in:] The Apocryphal New Testament..., p. 224-228.

${ }^{31}$ This story is also known to function as a compositional element of more substantial works, e.g. the Tale of the Passion attributed to John Chrysostom; cf. the Slavic text: Ижє в сватынх штьца нашего Їоанна Залтооүстаго архїєпископа Константіна града слшво о страсти Gпасовъ, in: Gj. PolívKa, op. cit., p. 124-129.
} 


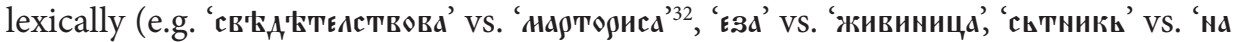

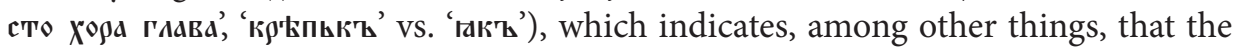
particular variants were composed in different places and at another time.

Nevertheless, the structure of the text is noteworthy: although she is the title character, and - as the protagonist - the ultimate cause of the described events, Martha's presence and part in the story actually come to an end halfway through the text, when the emperor is baptized by Lazarus and Longinus. Despite that, we are dealing with a beautiful example of an enhancement of a New Testament story, drawing its 'reliability' from the fact that the characters are set in a historical and geopolitical context (the emperor in Rome, the journey to the capital with a complaint about the prefect of a province).

The Tale of Martha, drawing on motifs present in a number of texts narrating the Passion and death of Christ and the fate of His disciples after the Resurrection (Anaphora Pilati, Paradosis Pilati, Tiberii Rescriptum), is considered an original Slavic compilation. In view of the topics to which it pertains, the Tale of Martha, representing an independent, autonomous text, should be granted a place in the Pilate Cycle, which is a comparatively new concept ${ }^{33}$ - unfortunately still not consistently adhered to $^{34}$. Nonetheless, there are additional aspects of the Tale of Martha corroborating its affinity to the Pilate Cycle, for instance in the domain of typology. The Gospel of Nicodemus features an episode in which, upon the entry of Jesus into the interrogation chamber, the images - that is, the top parts of the standards held by the soldiers - bow down in respect ${ }^{35}$. In the Tale of Martha, Christ's robe causes the ground in

${ }^{32}$ In each of the pairs the first member is the form attested in the $17^{\text {th }}$ century (?) Serbian version of On How Martha Judged Pilate Before Emperor Augustus as edited by: Gj. PolívkA, op. cit., p. $115-118$, while the second member is the form taken from the $18^{\text {th }}$ century copy from codex no. 437 (the so-called codex from Kotlen) stored in the St.St. Cyril and Methodius National Library in Sofia (cetera: NBKM), f. 22'-25'.

${ }^{33}$ The Medieval Gospel of Nicodemus..., p. 9.

${ }^{34}$ Thus, e.g. in the Polish three-volume anthology of the New Testament apocrypha edited by Marek Starowieyski (Apokryfy Nowego Testamentu, ed. M. StARowiEYSKI, vol. I-III, Kraków 2001-2007) the Tale of Martha is not included, either in the part devoted to apocryphal gospels (where the Pilate Cycle belongs) or among the apocryphal stories about the Apostles.

${ }^{35}$ Episode I, 5-6: Now when Jesus entered, and the ensigns were holding the standards, the images on the standards bowed down and worshipped Jesus. And when the Jews saw the behaviour of the standards, how they bowed down and worshipped Jesus, they cried out loudly against the ensigns. But Pilate said to them, 'Do you not marvel how the images bowed and worshipped Jesus?' The Jews said to Pilate, 'We saw how the ensigns lowered them and worshipped him'. And the governor summoned the ensigns and asked them, 'Why did you do this?' They answered, 'We are Greeks and servers of temples: how could we worship him? We held the images; but they bowed down of their own accord and worshipped him.' Then Pilate said to the rulers of the synagogue and the elders of the people, 'Choose strong men to carry the standards, and let us see whether the images bow by themselves.' So the elders of the Jews took twelve strong men and made them carry the standards by sixes, and they stood before the judgement-seat of the governor. And Pilate said to the messenger, 'Take him out of the praetorium 
the imperial palace to tremble, and it is only after Longinus returns without it and its power is confirmed that the emperor accepts Martha's words about Christ as true:

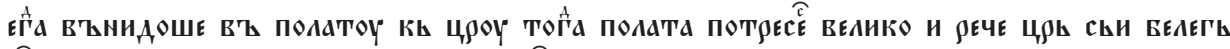

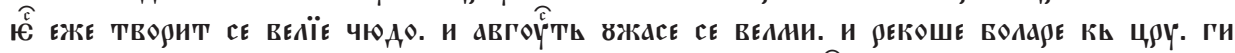

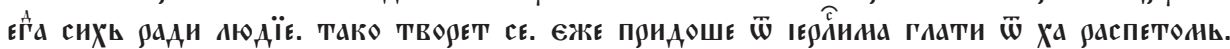

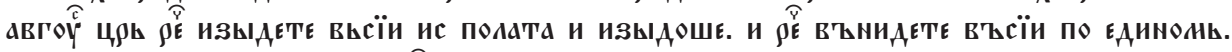

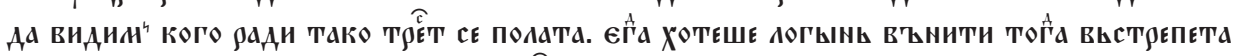

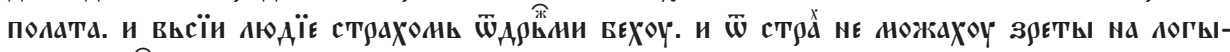

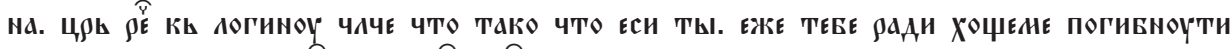

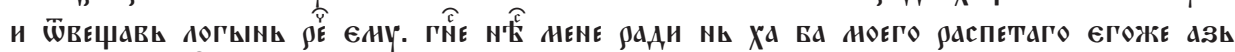

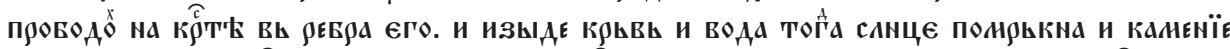

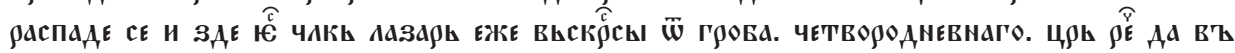

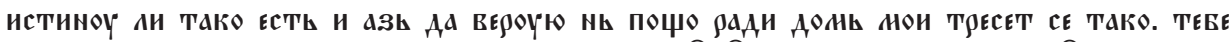

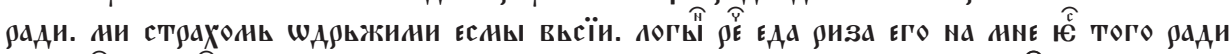

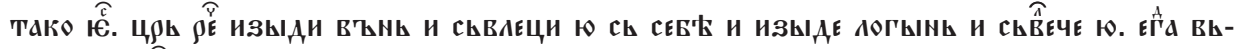

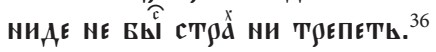

Certain similarities to this motif can also be found in the Byzantine and Syriac variants of the legend of king Abgar, in which a "great" 37 , "wonderful vision" 38 , seen

and bring him in again in whatever way you wish.' And Jesus left the praetorium with the messenger. And Pilate summoned those who had previously been carrying the images, and said to them, 'I have sworn by the salvation of Caesar that, if the standards do not bow down when Jesus enters, I will cut off your heads' And the governor commanded Jesus to enter in the second time. And the messenger did as before and begged Jesus to walk upon his scarf. He walked upon it and entered. And when he had entered, the standards bowed down again and worshipped Jesus - The Gospel of Nicodemus or Acts of Pilate, [in:] The Apocryphal New Testament..., p. 171-172.

${ }^{36}$ When they walked into the emperor's palace, the palace shook powerfully, and the emperor said: "This sign does a remarkable wonder", and Augustus was filled with great fear. The boyars told the emperor: "Lord, this is happening because of the people who came from Jerusalem to speak about the crucified Christ". Emperor Augustus said: "Go out of the palace, all of you" - and they went out. And he said: "Come in one by one, all of you, so that we can see because of whom the palace shakes in such a way". The palace shook at the moment when Longinus was about to enter, and all the people were struck with fear, and out of fright they could not look at Longinus. The emperor said to Longinus: "O human, who are you, so that we would have died because of you?" Answering, Longinus said to him: "Lord, not because of me but of Christ, my crucified God, whom I pierced in the ribs on the cross. And blood and water came out; then, the sun darkened and rocks cracked apart. And here is Lazarus, the man whom he had raised from his grave after four days". The emperor said: "If it is indeed so, I shall also believe, but for what reason does my house shake in such a way because of you? We are all seized with terror." Longinus said: "I am wearing His robe, this is why it is so". The emperor said: "Go out and take it off", and Longinus went out and took it off. When he went inside, there was no fear or shaking (translated from the Tale of Martha as preserved in manuscript NBKM 437; translation into English from the original as well as the author's Polish translation - M.M.).

${ }^{37}$ Eusebius, I, 13, p. 93.

${ }^{38}$ The Doctrine of Addai, the Apostle, trans. G. Phillips, London 1876, p. 6. 
only by the ill monarch, appears in the face of apostle Thaddaeus when the latter enters the palace in Edessa.

The juncture, therefore, between the Eastern and Western legends is to be sought at this very stage: Martha's journey to Rome. In the legends known in the West (including the legitimized literary texts of the Pilate Cycle), the women travelling to Rome (together or separately) are Mary Magdalene and Veronica, the latter carrying her precious relic attribute: the cloth that bears the image of Christ's face. In the East, conversely, this venturesome and zealous person (though not possessing any relics) is Martha; it is an image which fits perfectly into the practical aspect of her personality known to us from the Gospels ${ }^{39}$.

In the recent research (mainly of English and American scholars), predominantly such combining the fields of Biblical studies and sociology, the figure of Saint Martha is placed among the group 'loyal to John'. Emphasis is laid on the distinctive kind of her spirituality, committed to the effective organization of the religious community. This, however, comes dangerously close to the symbolic misuse of this character by feminist movements, attempting to turn Martha, one of the three most important women of the New Testament, into an almost prototypical efficient administrator and manager ${ }^{40}$.

\section{Veronica}

From among the three characters under discussion, Saint Veronica is beyond doubt the most familiar and widely known. She is commonly envisaged as the saintly, pious woman who, during the Passion, wiped Jesus' forehead with a cloth, and is regarded as the patron saint of photographers in view of this miracle. This episode, known in the West since the $4^{\text {th }}$ century, developed and spread especially owing to the Franciscan spirituality, finding its way into the Stations of the Cross. The canonical Gospels, though, mention neither her name nor even any such situation taking place: A large number of people followed him, including women who mourned and wailed for him. Jesus turned and said to them, "Daughters of Jerusalem, do not weep for me; weep for yourselves and for your children" (Luke 23, 27-28).

According to some sources, the woman who wiped Christ's face was called Seraphia. The name Veronica is thus claimed to be a later appellation, originating from the words vera icon 'real image', the latter having arisen in this peculiar way ${ }^{41}$. Older versions of the account attest the form 'Berenica' or 'Beronica', explaining it as

\footnotetext{
${ }^{39}$ In the Slavic (translation of?) On the Journey to Rome of Lazarus's Sisters, Martha and Mary, attributed to John Chrysostom, the sisters, accompanied by Longinus the centurion, speak to emperor Tiberius; cf. Сказание о приходе в Рим сестер Лазаря, Марфы и Марии, [in:] И.Я. ПорФИРьЕв, Апокрифическия сказания о новозаветных лицах и событиях по рукописям Соловеикой библиотеки, Санкт-Петербург 1890, p. 197-204.

${ }^{40}$ E. Moltmann-Wendel, The Women Around Jesus, London 1982.

${ }^{41}$ U. Janicka-Krzywda, Patron - atrybut - symbol, Poznań 1993, p. 84.
} 
Greek for 'bringing victory' ( $\phi \varepsilon ́ p \omega$ 'I bring', vík 'victory'). Some scholars find proof for the influence of the symbolism of blood in this process ${ }^{42}$ : the proper name 'Prunicos' or 'Prunica' designated - in the teachings of the Valentinian Gnostics - a personification or symbol of Wisdom, flowing from a virgin of the same name. 'Prunica' would have been substituted by 'Beronica' (along with yet another variant 'Bernice'), a wellknown and fairly popular name at the time ${ }^{43}$. Thus, the name of the originally anonymous Saint was probably 'picked' as a result of the contamination of different stories, whereas deriving it from the words 'true image' is a fairly late concept, secondary in comparison with the Early Christian stories (though substantiated by certain themes associated with the figure of the Saint).

Veronica of the Way of the Cross is unknown in the tradition of the Eastern Church, although two saints bearing this name are mentioned in liturgical calendars. The first of them is commemorated on 4(17) October. She is a martyr for the faith; this Veronica, together with her mother Domnina (Domna) and her sister Prosdoce, was halted by the soldiers of emperor Diocletian (305-306) on her way to Edessa and forced to turn back to their native Antioch; fearing disgrace on the side of the pagans, the three women prayed and threw themselves into the river, losing their lives ${ }^{44}$.

Possibly under the influence of their cult the woman who is supposedly the witness of the Passion, but is associated with the protagonist of a different Biblical episode, is at times referred to as a "martyr" in Slavic sources ${ }^{45}$. 12(25) July is the date of the commemoration of Veronica known as 'just' and 'saint.' The sticheron ${ }^{46}$ dedicated to her alludes to Christ's healing a woman suffering from bleeding, as described by Matthew $(9,18-26)$, Mark $(5,21-42)$ and Luke $(8,40-48)$ :

Mark 5, 25-34: And a woman was there who had been subject to bleeding for twelve years. She had suffered a great deal under the care of many doctors and had spent all she had, yet instead of getting better she grew worse. When she heard about Jesus, she came up behind him in the crowd and touched his cloak, because she thought, "If I just touch his clothes, I will be healed." Immediately her bleeding stopped and she felt in her body that she was freed from her suffering. At once Jesus realized that power had gone out from him. He turned around in the crowd and asked, "Who touched my clothes?" "You see the people crowding against you," his disciples answered, "and yet you can ask, "Who touched me?"' But Jesus kept looking around

${ }^{42}$ E. KunYLuK, Weronika i jej chusta. Historia, symbolizm i struktura „prawdziwego" obrazu, Kraków 1998, p. 14-15.

${ }^{43}$ J. NaUmowicz, op. cit., p. 47.

${ }^{44}$ Архиепископ Сергий (СпАСский), op. cit., p. 413; cf. also Święte niewiasty. Mały leksykon hagiograficzny, coll. et ed. J. Charkiewicz, Hajnówka 2001, p. 29.

${ }^{45}$ E.g. in the $16^{\text {th }}$ century prologues from the collection of the Church Historical and Archival Institute of the Bulgarian Patriarchate in Sofia, cat. no. 294 and 285.

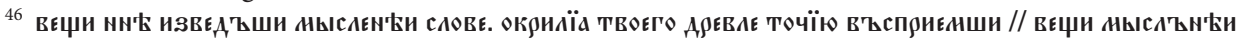

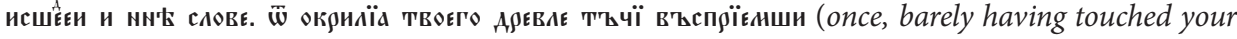
robe, she, [speaking] in other words, chased away the sensual matters) - Г. ПЕтКОв, op. cit., p. 436. 
to see who had done it. Then the woman, knowing what had happened to her, came and fell at his feet and, trembling with fear, told him the whole truth. He said to her, "Daughter, your faith has healed you. Go in peace and be freed from your suffering."

This anonymous figure of the woman suffering from bleeding appears in Early Christian Syriac and Greek works (a fact proved inter alia by Eusebius' citation in the Ecclesiastical History). She is also to be found in pseudo-canonical texts, e.g. in the Report of Pilate the Governor Concerning Our Lord Jesus Christ, Which Was Sent to Augustus Caesar in Rome, dating back to the $5^{\text {th }}$ century, the dramatic case of her sickness and healing is incorporated into the prefect of Judaea's account of the great deeds of Christ:

And [there was] a woman also, who had an issue of blood for a long time, and whose veins and arteries were exhausted, and who did not bear a human body, being like one dead and daily speechless, so that all the physicians of the district were unable to cure her. There remained to her not a hope of life, but as Jesus passed by she mysteriously received strength by his shadow falling on her from behind. She touched the hem of his garment and immediately, in that very hour, strength filled her exhausted limbs, and as if she had never suffered anything, she began to run along towards Capernaum, her own city, so that she reached it in a six days' journey. ${ }^{47}$

In a work belonging to the Pilate Cycle entitled The Avenging of the Saviour, earlier than the $9^{\text {th }}$ century, the suffering woman is also provided with a name. She testifies in front of the imperial emissary, Velosianus: And there came also the woman named Veronica, and said to him: And I touched in the crowd the fringe of His garment, because for twelve years I had suffered from an issue of blood; and He immediately healed $m e^{48}$. Needless to say, in both these passages a far-reaching influence of the Biblical story can be observed.

The Eastern Christian tradition quickly identified the woman healed by Christ with His follower, defender and possessor of His miraculous image. The seriously ill Tiberius (suffering from leprosy or having a wasp nest inside his head), having heard of Jesus, sent to Jerusalem an envoy (Velosianus) to bring him to Rome ${ }^{49}$. Upon hearing of the crucifixion, however, he ordered Pilate to be arrested and the witnesses of

${ }^{47}$ The Report Of Pilate The Governor, [in:] The Apocryphal Books of the New Testament: Being All the Gospels and Epistles Attributed to Jesus Christ, His Apostles and Their Companions, ed. W. Hone, ${ }^{2}$ Philadelphia 1901, p. 274.

${ }^{48}$ Quoted after: The Avenging of the Saviour, [in:] Ante-Nicene Fathers, vol. VIII, The Twelve Patriarchs, Excerpts and Epistles, The Clementina, Apocrypha, Decretals, Memoirs of Edessa and Syriac Documents, Remains of the First Ages, ed. A. RoberTs, J. Donaldson, A.C. Coxe, New York 1886, p. 474. Those words are also present in Veronica's letter to Herod.

${ }^{49}$ Once again it is possible to speculate the seeming exchangeability of characters within certain themes and motifs: king Abgar of Edessa also merely heard about Christ and desired to be healed by him. 
Christ's miracles (among them, the healing of the woman suffering from bleeding) to be summoned. Having recognized the Teacher as a godly figure, he was healed by looking at the image of His face alone, found on the canvas brought to Rome by Veronica. This story, narrated in various ways in the Pilate Cycle, exists in several versions. In some of them the owner of the precious relic decides to travel to Rome on her own; more often, however, she is summoned there to testify against Pilate or for Jesus. The accounts of her further fate vary as well. She may come back to Galilee; sometimes, on the other hand, she stays in Rome (having donated the valuable canvas to pope Clemens), or even acts as a Christian missionary in Western Europe (more specifically, Southern Gaul). According to some of the legends she was accompanied by her husband, the convert Zacchaeus known from the Gospel of Luke (Luke $9,2-10)$ - formerly the superintendent of customs, subsequently living the life of a hermit at the mouth of the Gironde (under the name Amadour). Not long thereafter, beginning in the $6^{\text {th }}$ century, similar accounts begin to surface in the West.

Let us, however, return to the episode described by Eusebius: the healed woman erecting a monument for the Saviour. Although she is known to us as Veronica, the Western commentators also gave her the name Martha, presumably as a simplification of the name Mariosa or Marosa, appearing frequently in this context and purportedly originating from an earlier aipoppoṽ $\sigma \alpha$ (haimorrousa) 'suffering from bleeding ${ }^{50}$. In this way, the moniker of a previously anonymous woman became a proper name. Thus, Martha finds her way into Western legends: for instance, Jacobus de Voragine, following the authority of Ambrosius, claims that out of the love for Mary Magdalene Jesus healed her sister from the issue of blood, from which she had been suffering for 7 years ${ }^{51}$.

In order to characterise the legendary figure of Veronica the most succinctly, then, one might perhaps venture the hypothesis that she reflects the convergence of two characters, in both of whom traces of Martha's presence can be detected: the ill woman from the Gospel and the woman holding the canvas during the Passion.

The legend of Veronica is, in a way, not original. That is to say, it derives from another text - or perhaps from variants and revisions of a text - containing similar elements. In the case at hand, the source is not particularly difficult to identify ${ }^{52}$. The text in question is the so-called legend of king Abgar - a pagan ruler of Edessa, who, having heard about Christ's miracles, decided to invite him to his city wishing to be healed from a condition from which he had been suffering for a number of years (gout or leprosy). Christ never arrived in Edessa, but he replied to Abgar by letter, blessing him and promising that he would be healed through his power by

\footnotetext{
${ }^{50}$ J. Naumowicz, op. cit., p. 49.

${ }^{51}$ Saint Mary Magdalene..., p. 376.

${ }^{52}$ Which task, as it happens, was accomplished over one hundred years ago, cf.: E. von Dobsснётz, Christusbilder. Untersuchungen zur christlichen Legende, Leipzig 1899.
} 
one of the disciples. The legend of Abgar - both in its legitimized versions (liturgical texts) and in the form of prayers or rites for the sick, or, finally, as represented on amulets - is thoroughly familiar to the nations of Slavia Orthodoxa (East and South). As per one of the variants of the legend, Luke (the apostle and evangelist) travelled to Edessa after the Ascension, carrying with him an image of Christ, "not of human making", to the sick Abgar. The latter, upon seeing it, recovered from his illness ${ }^{53}$. Typologically close versions of the tale of Veronica - supposedly the daughter of Abgar, receiving the miraculous image for her ill father, but at times also a noble lady or even queen, functioned first in the Syriac, then also the Byzantine tradition beginning in the $6^{\text {th }}$ century.

As far as Slavic texts are concerned, the presence of Veronica is not confined to pseudo-canonical works. Her story surfaces in the prologue life for the liturgical commemoration on 12 July, in itself a translation from the Greek and preserving the stage that the legend achieved, in the course of its development, around the $6^{\text {th }}$ century in the East. The text is only attested in late, $16^{\text {th }}$ and $17^{\text {th }}$-century copies (two of them published ${ }^{54}$ ) from the Slavic domain. Scholars have pointed to an excerpt of John Malalas' Chronicle as the intermediate source ${ }^{55}$. The prologue mentions a letter sent to Herod by a wealthy citizen of Paneas called Vernice (Veronica). In it, she describes the story of her distress, the bleeding that she had not been able to cure despite spending a fortune on doctors, and finally the Healer - Christ, whose power she had the honour to perceive (all of the above is known from the canonical Gospels, the Pilate Cycle as well as the account of Eusebius of Caesarea). The grateful Veronica intends to raise a monument for Christ; consequently, she has to ask for Herod's consent (this might echo the ancient tradition according to which erecting statues was banned as an improper form of worship, an interpretation mentioned by Eusebius himself). The intrigued king embraces the idea, after which a statue of Christ made of copper "with an admixture of gold and silver" is constructed, sometime later relocated from the centre of Paneas to the temple. This variant of the story deserves closer attention not only in view of its archaic character and consistency with the accounts of Early Christian writers, who comment e.g. on the composition of the alloy used in building the monument ${ }^{56}$. Equally interest-

${ }^{53}$ A version of the legend incorporated into the Tale of the Wood of the Cross by the Bulgarian priest Jeremiah ( $10^{\text {th }} / 11^{\text {th }}$ cent.); Polish translation: Opowieść o Drzewie Krzyżowym. Słowo i pochwała Mojżesza o splocie drzewa sosny, cedru i cyprysu, trans. M. Skowronek, [in:] Apokryfy i legendy starotestamentowe Słowian południowych, ed. G. Minczew, M. Skowronek, Kraków 2006, p. 187.

${ }^{54}$ Легенда о кровоточивой жене, Веронике, поставивщей образ Спасителя в Панеаде, [in:] И.Я. Порфирьев, ор. сіt., p. 279-281. Сf. Апокрифи і лезенди з українських рукописів..., p. 362-364.

${ }^{55}$ Ioannis Malalae Chronographia, 11-12, rec. J. ThURn, Berolini et Novi Eboraci 2000 [= CFHB, Series Berolinensis, 35]; Апокрифи і леленди з українських рукописів..., p. 364.

${ }^{56}$ Bronze with an admixture of gold and silver, since its glitter had the colour of amber; bizarre brightness: this is how the statue was described by Theodosius and Gregory of Tours, cf: J. NAumowicz, 
ing is the very form of the letter and Veronica's first-person account, which corresponds closely with the tradition of numerous pseudo-canonical letters associated with both the miraculous image of Christ (Abgar's letter and Jesus' response) and the correspondence widely represented in the Pilate Cycle (Anaphora Pilati, Letter of Pilate and Tiberius, Letters of Herod and Pilate), both as 'independent' texts and incorporated into larger collections.

Tracing the lives of Martha and Veronica (as literary characters), one cannot resist the impression that their stories are strikingly similar to one another. On the one hand we are dealing with a contamination of the two figures, seen in the stories about the cured bleeding, the journey to Rome and testifying the deeds of Christ; on the other hand, it appears that both Saints have different images in the traditions of the Eastern and the Western Church (in the West, the sympathetic Veronica accompanies Christ during the Passion, whereas Martha is a missionary in France). Their stories are intertwined because of related motifs - also background ones, as for instance the healing plant that sprouted at the feet of the statue of Christ in Paneas ${ }^{57}$, and its counterpart from the part of France where Saint Martha is said to have dwelled the herb which is called the 'dragon's wort' (artemisia dracunculus sativa or tarragon; dracunculus is Latin for 'little dragon') in commemoration of the Saint's subduing the ferocious creature. The plant is used as a remedy for insomnia, indigestion, menstrual problems and other issues.

\section{Longinus}

In the Early Christian tradition, the name of Longinus became associated with a character present during the scene of the Crucifixion, anonymous in the canonical Gospels. This is what we learn about him from the Scripture:

Matthew 27, 54: When the centurion and those with him who were guarding Jesus saw the earthquake and all that had happened, they were terrified, and exclaimed, "Surely he was the Son of God!"

Mark 15, 39: And when the centurion, who stood there in front of Jesus, saw how he died, he said, "Surely this man was the Son of God!"

Luke 23, 46-47: Jesus called out with a loud voice, "Father, into your hands I commit my spirit." When he had said this, he breathed his last. The centurion, seeing what had happened, praised God and said, "Surely this was a righteous man."

John 19, 34: ... one of the soldiers pierced Jesus' side with a spear, bringing a sudden flow of blood and water.

op. cit., p. 49.

${ }^{57}$ [A] this feet on the monument itself a strange species of herb was growing, which climbed up to the border of the double cloak of brass, and acted as an antidote to all kinds of diseases, quoted after: Eusebius, VII, 18, 3 (vol. II, p. 177). 
There is no certainty as to when the soldier/centurion, lacking a name in the canonical Gospels, was provided with one. It can be fairly certainly attributed to a folk etymology based on the Greek word for spear $\left(\lambda \sigma^{\prime} \gamma \chi\right)^{58}$; it also echoes the attributes of the weapon that the character wielded, and using which he pierced Christ's side (Lat. longus 'long'). Irrespective of that, Longinus promptly became a rewarding character for the legend rooted in the testimony of Mark, Matthew and Luke, where he is shown to have confessed faith in the true God immediately after the Crucifixion. The succinctness of John the Evangelist's account proved hardly a constraint for the Christian tradition, which has ascribed to Longinus a beautiful spiritual path: from a (perhaps involuntary) executioner of God to a confessor and martyr. Already Gregory of Nyssa speaks of him as the first evangelist and bishop of Cappadocia, where Longinus is said to have settled after leaving Jerusalem, which proves the existence of the Saint's cult at least as early as in the $4^{\text {th }}$ century $y^{59}$.

From among the three characters under discussion, Longinus is the best 'documented' in officially legitimized texts (that is, those used in liturgy) ${ }^{60}$. Namely, we are in the possession of all types of texts needed for celebrating the Saint's liturgical commemoration (at least in the Greek language) ${ }^{61}$ : two kinds of the prologue life (both 'standalone' and with sticheron), the extended life and the service (Slav. služba) penned by Theophanes the Confessor $\left(8^{\text {th }} / 9^{\text {th }} \text { cent. }\right)^{62}$. What is more, the author of the life of Longinus is Saint Hesychius - an outstanding commentator of the Scripture, a student of Gregory of Nazianzus (the Theologian) and a presbyter in Jerusalem (died 434 / after 450) ${ }^{63}$. In his opinion, Longinus was born in a place called Sandralis (or Adrales) near Tyana.

The earliest official text devoted to Longinus, the life (sometimes also referred to as a passion) written by Hesychius, is preserved in as few as six Slavic copies, of which the oldest ones date back to the $14^{\text {th }}$ century ${ }^{64}$. It is a translation of Hesychius

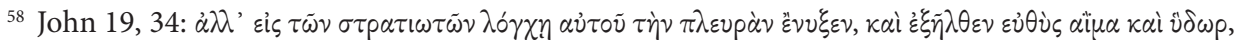
quoted after: Новый Завет на греческом и русском языкках, ed. А.А. Алексеев, Москва 2002.

${ }^{59}$ Letter XVII, 15, [in:] Gregory of Nyssa, The Letters, trans. A.M. Silvas, Leiden-Boston 2007, p. 166 [= Supplements to VC, 83].

${ }^{60}$ Cf. the comprehensive study: G. Orsola, San Longino nella tradizione greca e latina di età tardoantica. Analisi, commento delle fonti e contesto agiografico, Perugia 2008.

${ }^{61}$ The sticheron for the Saint reads as follows: живъ Боү

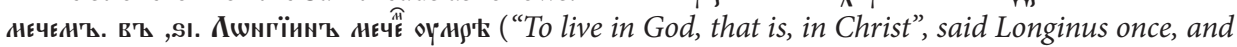
was beheaded with a sword. On the sixteenth [of October] Longinus was killed with a sword"), quoted after: Г. Петков, op. cit., p. 265.

62 Архиепископ СЕРгий (СПАССКий), op. cit., p. 429.

${ }^{63}$ On Hesychius cf. И.К. Цоневски, Патрология. Живот, съчинения и учение на иърковните Отии, учители и писатели, София 1986, p. 358.

${ }^{64}$ К. ИвановА, op. cit., p. 250-251 (16 October). The Byzantine tradition is richer in this respect: the BHG notes three texts (+ variants), no. 988-990; cf. PG, vol. XCIII, col. 1545-1560 and PG, vol. CXV, col. 32-44. 
text with chapter 16 omitted. The work is an early and therefore potentially credible testimony of the legends connected with the Saint. Thus, Longinus is held to have been one of the more senior in rank of the Roman soldiers, the commander of the unit that was ordered to guard Christ's tomb. When the Jews offered him money in return for testifying that Christ had not risen from the dead, but his body had been stolen by the disciples, he refused and, accompanied by two fellow soldiers ${ }^{65}$, left Jerusalem for his native Cappadocia. There, he lived in holiness, preaching to pagans $^{66}$. Still, upon learning about Longinus calling Christ the king of nations, Pilate - in cooperation with the emperor (Tiberius) and in order to appease the latter's anger - sent two people with a mission to kill the centurion. Coming across emissaries seeking a certain Longinus, the Saint did not reveal his identity, instead inviting the guests to his house and hosting them for three days - knowing that he is the one searched for, facing punishment by death. Afterwards, he summoned his companions, so that they might die alongside him for the glory of the true God. The envoys initially refused to execute the sentence on their cordial host, but eventually, seized by fear of Pilate, they carried out the order. In return for a sum of money, the governor traded the Martyr's head to the Jews, who threw it away onto a heap of dung. After some time had passed, a blind woman came to Jerusalem with the intention of visiting a number of holy places, aided by her only son, who, however, died unexpectedly on the way. Saint Longinus appeared in the woman's dream, commanding her to find the disgraced head and promising to reward her for the suffering and misery she had gone through. All this indeed happened - after locating the precious relic, the woman regained sight, once again seeing Longinus in her dream, this time with her son in his arms. The latter explained to her that she should bury the holy head together with his body, so that he might enjoy eternal happiness. Having carried out the instructions, the widow experienced yet another vision in her dreams, in which she was assured about her son's felicity "among the prophets".

The story is remarkable because of an array of ostensibly trivial details. Firstly, Longinus as presented here has scarcely anything in common with Christ's death on the cross: he is but a guard at His tomb, which might point to an attempt on the side of Hesychius to 'soften' the image of the executioner of Christ, an endeavour to 'whitewash' the Saint's true story (i.e. the one appearing in the canonical Gospels). Secondly, no doubt under the influence of Gregory of Nazianzus, Hesychius makes every effort to depict Longinus as the one who brought Christianity to Cappadocia,

\footnotetext{
${ }^{65}$ The soldiers who, having abandoned the service in the Roman army and arrived in Cappadocia along with Longinus, lost their lives and were worshipped as martyrs, are traditionally known as Isaurus and Aphrodisius. They are commemorated on 19 April in the liturgical calendar.

${ }^{66}$ Similarly in other Western versions of the legends, cf. Żywot Świętego Longina, żolnierza i męczennika, [in:] P. SKARGA, op. cit. (http://ruda_parafianin.republika.pl/swi/l/longin.htm [20 X 2011]).
} 
comparing him with Thomas the Apostle in India, Peter among the Romans or Paul in the lands ranging from Jerusalem to Illyria. Thirdly, the blind woman arrives in Jerusalem from Cappadocia, thus repeating the path of Longinus, who in this way became a kind of local patron. This was probably meant to corroborate the image of Cappadocia as 'the chosen land', which task Hesychius carried out quite convincingly. Finally, Longinus was ascribed post mortem miracles (appearing in the dreams of the woman in need of help, guiding and healing her as well as restoring her sight).

Hesychius opted for this particular kind of disability with a clear aim in mind. There also exists a motif (Greek in origin) of the blindness of Longinus himself; the condition is said to have been cured by the blood and water flowing out of the Saviour's pierced side. This event initiated the spiritual change in Longinus, formerly Cassius. More probably, however, as a soldier of the Roman army, he was not entirely blind, but had poor eyesight or was blind in only one eye. One of his commanders, the one who had already executed Longinus for his refusal to worship idols, descended into insanity and lost his sight until the moment when Longinus interceded for him. Stories on losing and regaining sight would become the leitmotif of the character of Longinus, present in virtually every single text devoted to him, including the iconographic ones ${ }^{67}$.

However, the Western tradition (Bollandists) distinguishes between two separate characters, in all likelihood due to the divergent accounts of the Four Gospels as to who pierced Christ's side. The first of them is the soldier (originally) called Cassius, from Isauria, who thrust his spear into the Lord's body and, having adopted the name Longinus, died a martyr's death in Caesarea (in Cappadocia) (the date of the liturgical commemoration varies from church to church: 15 March, 22 November, 2 December). The other is a centurion from Adrales near Tyana (in Cappadocia), who under the Cross admitted that Christ was the Son of God (commemorated on 16 November $)^{68}$. Certain accounts even specify the name of this centurion: Gaius Cassius Longinus, which is in accordance with both traditions ${ }^{69}$. In the version of the story found in the Legenda Aurea, Longinus returned to Cappadocia, where he lived for 38 years as a monk $(!)^{70}$. In Italy, there is a widespread legend according to which Longinus, after conversion, brought a lead casket full of earth soaked with the Lord's Blood to Mantua and buried in the place where the Basilica of St. Andrew stands today. Not long after that, he attained martyrdom and was buried in the vicinity of the relics ${ }^{71}$. (The murals in the local chapel portray the scene of the Crucifixion with

\footnotetext{
${ }^{67}$ J. JAGLA, Oko i serce. Apokryficzna postać Longinusa w sztuce średniowiecznej, [in:] Biblia Slavorum..., p. 221-230.

${ }^{68}$ АрхиеПископ СЕРГИЙ (СПАССКИЙ), op. cit., p. 428-429.

${ }^{69} \mathrm{http}: / /$ bibleprobe.com/holy_lance.htm [20 X 2011].

${ }^{70}$ According to the English translation of the Legenda Aurea [in:] www.catholicforum.com/saints/ golden 174.htm [20 X 2011].

${ }^{71}$ Cf. S. Traynor-Morawska, Longino soldato Romano di Lanciano, Lanciano 1999.
} 
Longinus kneeling, collecting Christ's Blood into a chalice). Longinus is commonly regarded as the patron saint of horse riders and trainers ${ }^{72}$.

The oldest Slavic copies of the prologue lives, read during the service (officium) on the day of Saint Longinus, come from the $14^{\text {th }}$ century.

The so-called Lesnovo Prologue, $1330^{73}$

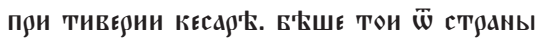
КАПОАОКЕНСКЫН.

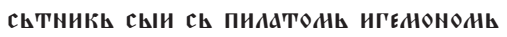
июдтискыиды.

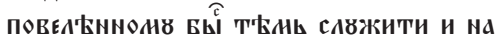

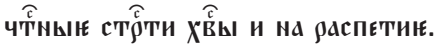

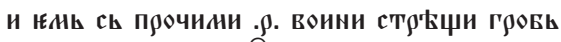
с КУСТОАННЮ. ИЖе Ю्

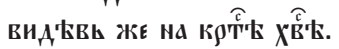

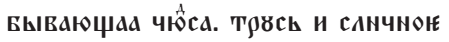
ПОНЛАЧЕнИҢ.

И ӤВЛЗАЕЩЕЕ СЕ ГЛОБЫ ВИСТАЕЩЕЕ НОТВЦЕ.

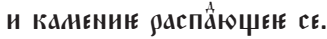

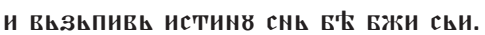
WСТАВАЬ ЖЕ СУЧЕЕ ЕГО ВОННСТВО. И СВОН

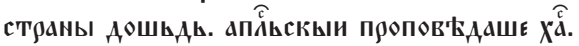

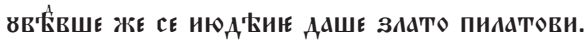

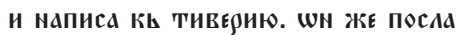

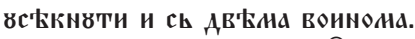

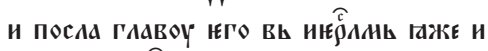

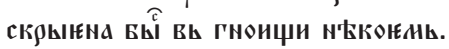

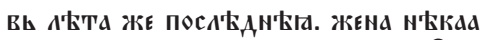

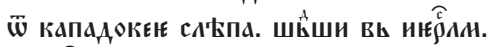
ші вжеттнаго василига.
The so-called Przemyśl Prologue, $16^{\text {th }}$ century $^{74}$

Аогинь с'ътник стық дчнк'

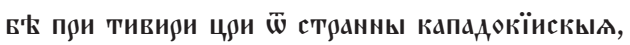

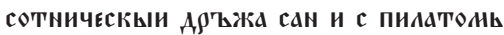

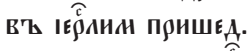

Вไ В९КНА ЖЕ СТ

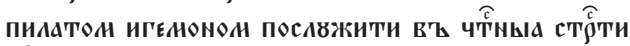

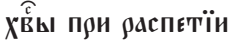

и с' КУСТОАНЕН, ЕЖЕ ЕСТЬ ЧИНЬ ВОИНЫЧЕСКЫИ.

ВИА'Т ВЖЕ ХА ПЛЕААВ ПЛЕБИША ОАЗБОИнИКОНА ГОАЕнИ,

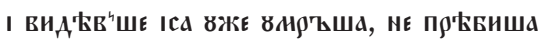

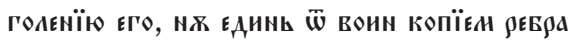

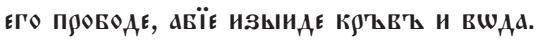

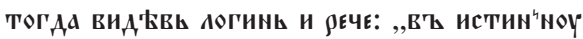

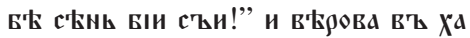
И ШСТАВИ ВШИНСТВО И АОШЕА СВОЕА СТ ЛАНЫ

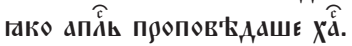

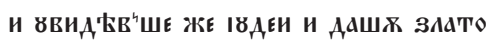
ПИААТОВИ, АА ЕГАА ЕГО ПОГОУБИТ.

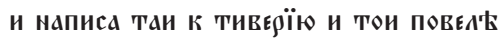

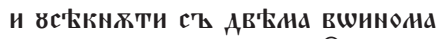

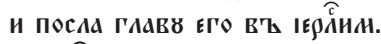

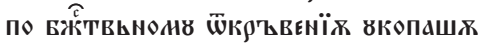

Х ИВАЕЕ В'Қ ГНОИ N'ККОЕН.

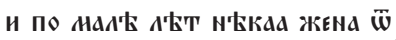

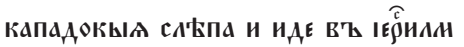

${ }_{72}$ G. LANZI, F. LaNZI, Saints and Their Symbols: Recognizing Saints in Art and in Popular Images, Collegeville 2004, p. 49.

${ }^{73}$ The so-called Lesnovo Prologue from 1330, f. 40'-41, text edition: Станиславов (Лесновски) пролог от 1330 година, еd. Р. Павлова, В. Желязкова, Велико Търново 1999, р. 58-59.

${ }^{74}$ The so-called Przemyśl Prologue from the $16^{\text {th }}$ century, f. 287-288; edition of the text in: Anokрифи і легенди з українських рукописів..., p. 366. 


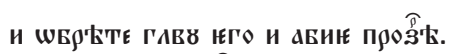
ТОГО ААТВАНИ $\chi^{\overparen{C}}$ БE NШь. ${ }^{75}$

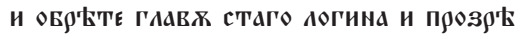

и поослави Ха ва. ${ }^{76}$

Although in both cases we are dealing with the same literary genre, and - at any rate theoretically - with the same text, far-reaching differences in the treatment of the material are observable. The earlier version appears to be less coherent and more poorly organized - but on the other hand consistent with the synoptic gospels' attitude towards Longinus, 'whitewashing' him to a certain degree by slightly downplaying his role in the Crucifixion.

The prologue preceded by the sticheron largely draws from the type of the simple prologue. In fact, its first part corresponds to the simple prologue without any major modifications; the difference consists in the treatment of the second part, describing the post mortem miracles, i.e. the story of the healing of the blind woman. In particular, certain additional details of this episode are brought to light, whereas in the simple prologue the whole story is covered by a single sentence. The account is in full compliance with the life by Hesychius:

After many years a certain woman from Cappadocia, having gone blind in the eyes, came

${ }^{75}$ [The Saint Martyr Longinus] of the Cappadocian land lived during [the reign of] emperor Tiberius, with Pilate the hegemon of Judaea. By the latter, he was ordered to serve during the holy Passion of Christ as well as the Crucifixion, and to guard the Tomb with another one hundred soldiers (a military unit) on sentry duty. Having seen the wonders happening at Christ's Cross, the earthquake and the eclipse of the sun, graves opening and the dead rising, and rocks cracking apart, he cried: "Truly this was the Son of God". Leaving behind his unit and returning to his native land, he preached Christ like an apostle. Having discovered this, the Jews gave gold to Pilate, and he wrote to Tiberius. The latter ordered him [Longinus] to be beheaded together with two soldiers [who had deserted the army with him]. And he sent his head to Jerusalem, where it was hidden in some pile of dung. During the later years, a certain blind woman from Cappadocia, having come to Jerusalem from Saint Basil, found his head and immediately regained sight owing to his [Longinus'] prayers. (translated into English from the original as well as the author's Polish translation - M.M.).

${ }^{76}$ Longinus the Centurion, the Holy Martyr from the Cappadocian land, lived during [the reign of] emperor Tiberius. He held the rank of a centurion and came to Jerusalem with Pilate. At the time of the Lord's Passion, he was ordered by hegemon Pilate to serve during the Crucifixion, and to guard the Tomb with another one hundred soldiers (a military unit) on sentry duty. He saw that Christ had already given up the ghost, when the soldiers pierced the criminals' shins, and - seeing Christ already dead-did not pierce His shins, but one of the soldiers pierced His ribs with a spear, and immediately blood and water flowed out. Seeing this, Longinus said: "Indeed this man was the Son of God". And he believed in Christ. And he left behind his unit, and having reached his native land he preached Christ like an apostle. Having discovered this, the Jews gave gold to Pilate, so that he would kill him. And he wrote to Tiberius, and the latter ordered him [Longinus] to be beheaded together with two soldiers [who had deserted the army with him]. And he sent his head to Jerusalem. According to God's will, the Jews buried it in some dung. After some years a certain blind woman from Cappadocia went to Jerusalem and found the head of Saint Longinus, and regained sight, and praised God (translated into English from the original as well as the author's Polish translation - M.M.). 
to Jerusalem with her only son, in order to visit the holy places and find rescue for her eyes as well as for the [suddenly] deceased son. In despair, she wailed mournful songs. In a dream, the blessed Longinus appeared to her and told her where his head had been hidden, and ordered her to dig it up and take it, and in this way she should be healed and see her son in glory. Upon this demand, having found the heap of dung and dug up the head with her hands, she took it and returned from blindness to sight. In a dream, she saw her son together with the Saint, receiving honour from him. Having buried her son's body together with the Saint's head, as she had been commanded to do, she went to Cappadocia. As in the parable of Saul, in which he searched for his father's donkeys and received the kingdom [1 Samuel 9, 1-16], thus also she gained healing for her eyes and an ardent helper and advocate [in the Saint]. Having erected a beautiful church there, she placed the Saint's body there, the source of healing for everyone ${ }^{77}$.

Although liturgical practice legitimizes legends, placing them in an official context, Longinus - in view of his participation in the Crucifixion - remains one of the constant characters of pseudo-canonical works dealing with the Passion. In the Tale of Martha, mentioned above, he is in fact a prominent figure, as the possessor of Christ's robe showing the Saviour's power and as the one who baptized the emperor, himself being an excellent example of a convert infidel. Significantly, this proves that he has been ascribed not only post mortem miracles and appearing to the faithful in revelations, but also curing the sick still during his lifetime - not limited to illnesses related to eyes. Longinus is mentioned abundantly in the Gospel of Nicodemus, where he appears not just as a nameless centurion $(11,2)$, but also as "Longinus the soldier" who "pierced his side with a spear" $(16,7)^{78}$.

In the Letter of Pilate to Herod, dating back to the $5^{\text {th }}$ century, Longinus (alongside Pilate's wife, Procla) is the primary witness of Christ meeting His disciples after the Resurrection:

And now when Procla my wife heard that Jesus was risen, and had been seen in Galilee, she took with her Longinus the centurion and the twelve soldiers who watched the tomb, and went forth, as it were to a great sight, to welcome the person of the Messiah. And she saw him along with his disciples. And whilst they were standing in astonishment looking upon him, he looked upon them and said to them: "What is it? Do ye believe on me? Know, Procla, that in the testament which God gave to the fathers, it is said, that every body which had perished, should live by means of my death, which ye have seen" ${ }^{79}$

It is not only the Saint himself who became the subject of Christian leg-

\footnotetext{
${ }_{77}$ Prologue from the collection of the Library of the Bulgarian Academy of Sciences, cat. no. 74, f. 79'-80' (translated into English from the original as well as the author's Polish translation M.M.).

${ }_{78}$ The Gospel of Nicodemus or Acts of Pilate, [in:] The Apocryphal New Testament..., p. 184.

79 The Letter of Pilate to Herod, [in:] Apocrypha Anecdota. Second Series, ed. M.R. JAmEs, Cambridge 1897, p. 71-72.
} 
ends. The tool which he used during the Passion, known as the Spear (or Lance) of Longinus or the Spear of Destiny, was an object desired by numerous rulers, even beyond the Christian world ${ }^{80}$. Longinus has also been considered by some to be the one who collected the Blood flowing from Christ's pierced side into a vessel during the Crucifixion, thus linking the Saint with the legends about the Holy Grail ${ }^{81}$.

$* * *$

Needless to say, the group which was above conventionally described as the 'first witnesses' could easily be expanded. In the light of canonical and pseudo-canonical, apocryphal or even historical texts, further figures that demonstrated strong attachment to Jesus and His teachings might be added to it: Joseph of Arimathea, Nicodemus and Gamaliel (e.g. in the Gospel of Nicodemus), or the ruler of Edessa, Abgar, whom we have mentioned a number of times already - a historical figure, 'manipulated' in a way within the pseudo-canonical tradition. Taking into consideration certain other texts, even Pontius Pilate as well as his wife, called Claudia Procula (or Proculla/Procla), worshipped as a saint in the Ethiopian church, could be considered as candidates. Obviously, all those characters appear in a context much wider than the preserved Slavic texts: namely, in Byzantine, Syriac, Armenian, Georgian, Coptic and also Latin sources.

As far as the number of texts is concerned, the Slavic tradition cannot match the incomparably more abundant Byzantine or Latin ones. Still, even within this area certain variation in the texts can be observed, which demonstrates that the Slavic tradition also sought its own mode of expression, though at a later time.

Even so, the characters (also in a literary sense) of Martha, Veronica and Longinus, examined against the background of the monuments of Christian literature, enable us to formulate a number of arguments concerning the cult of the saints in general.

Firstly, they illustrate the problematic point of the 'recognizability' in the worship of the saints, indicating the relations between saints bearing the same name. The 'Biblical' Veronica, known from the legend about the healed woman, is at times referred to as a 'martyr' - no doubt owing to the influence of the cult of another saint by the same name, indeed a martyr. (The fact that both of them are connected with

${ }^{80}$ The history of this relic has been described in detail in: M. Hesemann, Die stummen Zeugen von Golgatha: die faszinierende Geschichte der Passionsreliquien Christi, München 2000. Cf. also e.g.: A. BAKER, Invisible Eagle. The History of Nazi Occultism, London 2000, p. 84-94 (chapter 5: Talisman of Conquest. The Spear of Longinus).

${ }^{81}$ As regards the abundant literature devoted to the identifications of the Holy Grail, cf. a number of studies that connect its story with the character of St. Longinus: C. KRÖNER, Die Longinuslegende, ihre Entstehung und Ausbreitung in der französischen Literatur, Münster 1899; R. PeEbles, The Legend of Longinus in Ecclesiastical Tradition and in English Literature and its Connection with the Grail, Baltimore 1911 [= Bryn Mawr College Monographs, 9]; J.R. Doner, The Knight, the Centurion, and the Lance, Neo 77, 1993, p. 19-29. 
the same place - Edessa - cannot have facilitated distinguishing between the two). The situation is quite similar as far as Martha and Mary from Bethany are concerned: conceivably, the two are called martyrs due to the interpolation of the sisters called Martha and Mary who were beheaded with a sword. Through the attempts to differentiate between certain characteristics of the 'soldier' or 'centurion' known from the Gospels, the 'dual' figure of Longinus was constructed (the soldier of 15 March and the centurion of 16 October). The occurrence of part of the contaminations of this sort may be ascribed to the lack of clarity in the Biblical text (as in the case of Longinus), while others can be explained as the result of the impact exerted by certain motifs and the replacement of certain lesser-known characters (such as the martyr from Edessa/Antioch) by those more 'consolidated' in general awareness (the 'Biblical', healed Veronica).

Secondly, the genres of pseudo-canonical texts in which those characters appear seem to be inferior in no respects to the same genres known from the Biblical hypertext. Legends or 'tales' tend sometimes to quite successfully imitate the accounts of the fates of the Apostles (the voyages of Martha and Veronica, the teaching of Longinus), recalling the acta or gesta. The letters also pattern themselves after the canonical model of the genre, encompassing a range of topics much wider than mere caution or worry, and displaying the (often intricate) relations between the sender and the addressee while depicting the same situation from several perspectives.

Thirdly, it becomes apparent how texts which - perhaps merely seemingly, at first glance - are supposed to recount the lives of saints in fact serve purposes that are not that saintly at all. This is especially visible in the Western adaptations of motifs of Eastern origin: the depiction of Veronica, Mary Magdalene and Martha or Longinus stay in Gaul or northern Italy is to aid the cause of 'ennobling' or even 'archaizing' the history of the local Christianity.

Finally, maybe even more significant and interesting than the fate of the three New Testament (and simultaneously 'pseudo-canonical') characters are the literary/cultural planes on which they come to meet: the Tale of Martha, the Gospel of Nicodemus or the story about the woman from Edessa/Paneas healed from the issue of blood. It turns out that the legends are inspired by the canonical text (fragmentary in many respects) on the one hand, while on the other hand they themselves infiltrate official texts - they become officially sanctioned as soon as their popularity (in a good sense) is taken over and adopted by liturgical practice. It should be borne in mind that those legends - part of which is known both in Eastern and in Western Christianity - confirm one further crucial characteristic of texts constituting the canonical and pseudo-canonical tradition: the commonness of themes and motifs which can without exaggeration be called 'wandering. They determine the fact that there is hardly any originality in the formation of the characters of patron saints; moreover, on the level of creating the notion of sainthood and its reception, there seem to be far more 
common points than differences between both of the Early Christian traditions - the East and the West.

Abstract. The epithet 'first witnesses', conferred on the three saints in the title, is but a conventional designation; it seems fitting as common for the figures of saints, who gave proof of their devotion to Christ. Otherwise, although they make no simultaneous appearance in any of the canonical texts, there are - interestingly - far more interconnections between the three characters in pseudo-canonical and legendary literature than could be surmised from the lack thereof in the Bible.

The aim of the paper is to present a literary picture of three New Testament heroes, as commemorated in different literary texts representing diverse cultural registers, even from the Ancient Christian Times until the close of the Middle Ages. Among them there are short and extended lives and passions of saints, liturgical poetry, as well as specific, more popular texts, such as 'tales' and legends. The material under discussion largely includes texts that form a part of the Slavic Orthodox tradition, depicting them on the background of fairly wellknown works belonging to the Western Christian tradition.

It turns out that the legends are inspired by the canonical text on the one hand, while on the other hand they themselves infiltrate official texts - they become officially sanctioned as soon as their popularity is taken over and adopted by liturgical practice. It should be borne in mind that those legends - part of which is known both in the Eastern and in the Western Christianity - confirm one further crucial characteristic of texts constituting the canonical and pseudo-canonical tradition: the commonness of themes and motifs which can without exaggeration be called 'wandering. They determine the fact that there is hardly any originality in the formation of the characters of patron saints; moreover, on the level of creating the notion of sainthood and its reception, there seem to be far more common points than differences between both of the Early Christian traditions - the East and the West.

The paper is an attempt to point out how the Christian tradition exemplifies various manifestations of holiness, what means it has for annotating, elucidating and embellishing the Biblical hypertext, and how it adapts pseudo-canonical legends for the purposes of liturgical use.

Translated by Marek Majer

Małgorzata Skowronek

Zakład Paleoslawistyki i Kultury Ludowej Katedra Slawistyki Południowej Uniwersytetu Łódzkiego ul. Lipowa 81

90-568 Łódź, Polska skowronek.malgo@gmail.com 